UDK: 338.439 .02

\title{
Valentina ZAKHARCHUK
}

PhD in Economics, Associate Professor, Department of Expertise of Goods and Services, Odessa National Economic University, Ukraine, e-mail: zakharchukv@yahoo.com, ORCID ID: https://orcid.org/0000-0003-4739-3828

\section{Liliia NERUTSA}

Postgraduate student, Department of Expertise of Goods and Services, Odessa National Economic University, Ukraine, e-mail: lilyanerutsa758@gmail.com, ORCID ID: https://orcid.org/0000-0002-2670-2428

\section{THE BASIC PRINCIPLES OF THE STATE POLICY IN THE FIELD OF CONSUMER PROTECTION IN THE MARKET OF ORGANIC PRODUCTS}

\begin{abstract}
Zakharchuk, V., Nerutsa, L. (2018). The basic principles of the state policy in the field of consumer protection in the market of organic products. Ed.: M. Zveryakov (ed.-in-ch.) and others [Osnovni zasady derzhavnoi polityky shchodo zakhystu prav spozhyvachiv na rynku orhanichnoi produktsii; za red.: M. I. Zveriakova (gol. red.) ta in.], Socioeconomic research bulletin; Visnik social'no-ekonomičnih doslidžen' (ISSN 2313-4569), Odessa National Economic University, Odessa, No. 1 (65), pp. 60-68.

Abstract. The essence and advantages of organic production are investigated in the article. The actual problems of development of organic products market in Ukraine and the level of its information support for consumers are considered. The legislative and regulatory framework is analyzed and shortcomings in the legal provision for stimulating the activities of agrarian enterprises in Ukraine are identified. The creation of information support tools as a way of systematization of Ukrainian "organic farms» for the development of the organic market in Ukraine, the formation of a wide range of quality food products and the introduction of a unified certification control system, which will guarantee the high quality of food to the population as an important component of food security, are proposed. The importance of introduction of environmentally friendly production is determined, which, in turn, will improve the ways of integrated solution of environmental and economic problems.
\end{abstract}

Keywords: organic products; agricultural market; organic production; consumer protection; food safety; certification.

\section{Валентина Григорівна ЗАХАРЧУК}

кандидат технічних наук, дочент кафедри експертизи товарів та послуг, Одеський національний економічний університет, Україна, e-mail: zakharchukv@yahoo.com, ORCID ID: https://orcid.org/0000-0003-4739-3828

\section{Лілія Вікторівна НЕРУЦА}

аспірант кафедри експертизи товарів та послуг, Одеський національний економічний університет, Україна, е-mail: lilyanerutsa758@gmail.com,

ORCID ID: https://orcid.org/0000-0002-2670-2428

\section{ОСНОВНІ ЗАСАДИ ДЕРЖАВНОЇ ПОЛТТИКИ ЩОДО ЗАХИСТУ ПРАВ СПОЖИВАЧІВ НА РИНКУ ОРГАНІЧНОЇ ПРОДУКЦЇ̈}

Захарчук, В. Г., Неруца, Л. В. Основні засади державної політики щчодо захисту прав споживачів на ринку органічної продукиї // Вісник сочіально-економічних досліджень: зб. наук. праць (ISSN 2313-4569); за ред. M. І. Звєрякова (голов. ред.) та ін. Одеса: Одеський національний економічний університет. 2018. № 1 (65). C. $60-68$.

\footnotetext{
Анотація. У статті досліджено сутність та переваги виробництва органічної продукції. Розглянуто актуальні проблеми розвитку ринку органічної продукції в Україні та рівня його інформаційного забезпечення для споживачів. Проаналізовано законодавчо-нормативну базу та виявлено недоліки у правовому забезпеченні стимулювання діяльності аграрних підприємств в Украӥні. Запропоновано створення засобів інформаційного
} 
забезпечення як способу систематизаиії українських «органічних господарств» для розвитку органічного ринку в Україні, формування широкого асортименту якісних продуктів харчування та запровадження єдиної системи контролю сертифікачії, щуо гарантуватиме населенню високу якість продовольства як важливої складової продовольчої безпеки. Визначено важливість впровадження екологічно чистого виробництва, щүо покращить шляхи комплексного вирішення екологічних та економічних проблем.

Ключові слова: органічна продукція; сільськогосподарський ринок; органічне виробництво; захист прав споживачів; продовольча безпека; сертифікація.

\title{
Валентина Григорьевна ЗАХАРЧУК
}

кандидат технических наук, дочент кафедры экспертизы товаров и услуг, Одесский национальный економический университет, Украина, e-mail: zakharchukv@yahoo.com, ORCID ID: https://orcid.org/0000-0003-4739-3828

\section{Лилия Викторовна НЕРУЦА}

аспирант кафедры экспертизы товаров и услуг, Одесский национальный економический университет, Украина, е-тail: lilyanerutsa758@gmail.com,

ORCID ID: https://orcid.org/0000-0002-2670-2428

\section{ОСНОВНЫЕ ПРИНЦИПЫ ГОСУДАРСТВЕННОЙ ПОЛИТИКИ В СФЕРЕ ЗАЩИТЫ ПРАВ ПОТРЕБИТЕЛЕЙ НА РЫНКЕ ОРГАНИЧЕСКОЙ ПРОДУКЦИИ}

\begin{abstract}
Захарчук, В. Г., Неруиุа, Л. В. Основные принцииь государственной политики в сфере защиты прав потребителей на рынке органической продукции // Вестник соииально-экономических исследований: сб. науч. трудов (ISSN 2313-4569); под ред. М. И. Зверякова (глав. ред.) и др. Одесса: Одесский национальный экономический университет. 2018. № 1 (65). С. 60-68.
\end{abstract}

Аннотация. В статье исследовань сущность и преимущества производства органической продукции. Рассмотрены актуальные проблемы развития рынка органической продукиии в Украине и уровня его информационного обеспечения для потребителей. Проанализирована законодательно-нормативная база $и$ выявлены недостатки в правовом обеспечении стимулирования деятельности аграрных предприятий в Украине. Предложено создание средств информационного обеспечения как способа систематизации украинских «органических хозяйств» для развития органического рынка в Украине, формирование иирокого ассортимента качественных продуктов питания и внедрение единой системы контроля сертификации, что будет гарантировать населению высокое качество продовольствия как важной составляющей продовольственной безопасности. Определена важность внедрения экологически чистого производства, что, в свою очередь, улучшит пути комплексного решения экологических и экономических проблем.

Ключевые слова: органическая продукция; сельскохозяйственный рынок; органическое производство; защита прав потребителей; продовольственная безопасность; сертификация.

JEL classification: D180; Q120; Q130; Q180; Q580

\section{Introduction}

The production of environmentally friendly products is a practical implementation of the concept of sustainable development of agrarian production, which involves a combination of economic growth, social development and environmental protection as interdependent and mutually complementary elements of the strategic development of the state, which will guarantee the high quality food to the population as an important component of food security.

Ukraine has a particularly large potential for the development of organic production. Given the high natural fertility of soils, it is possible to obtain relatively high yields of agricultural crops without application of mineral fertilizers and agrochemicals. This means that Ukraine can produce organic products at a relatively lower cost than European countries, in which, due to the low natural fertility of soils, the transition to organic farming is accompanied by a significant increase in the cost price of organic products. Therefore, Ukrainian organic products are potentially more competitive, since 
its minimum price, which is the threshold of cost, is lower than the minimum price of organic products in European countries.

\section{Latest research and publications analysis}

Organic production relates to alternative methods of farming, based on a deep understanding of the processes occurring in nature, aimed at improving the structure of soils, reproducing their natural fertility and contributing to the creation of environmentally sustainable agro-landscapes. The scale of organic production is constantly increasing. It should be noted that organic produce in the world is grown on 31 million hectares of agricultural land in 120 countries.

Domestic and foreign scientists devote much attention to the study and research of this issue. Among domestic scientists, engaged in the study of foreign experience in the implementation of ecological agriculture, are V. Pidlisniuk, V. Artich, M. Kobets, P. Pisarenko, V. Saiko, B. Burkinsky, V. Milovanov, T. Zaychuk, T. Dudar and others. The urgency of further research is related to the need for environmentally friendly products in order to form the food security of the country.

The formation of an organic local food system leads to sustainable regional development, and as a result, agriculture and the food system of the region can provide not only the growing export rates, but also the intensive development of the domestic and local markets for organic products.

There is no single authorized body in Ukraine that monitors certified enterprises and an assortment of organic products at the national level. The level of information of the organic products market in Ukraine is low. The vast majority of organic farms, even if they have sites, do not provide them with information about the availability of a proper certificate, the range of their products, prices and delivery terms, as well as the shelf life and delivery time of a product.

The active growth of the domestic market for organic products is hampered by the lack of awareness of consumers about such products.

\section{The main material research}

The purpose of the article is to improve the principles of legal regulation of organic production in order to protect consumers' rights, as well as eliminate marketing discrepancies between producers and consumers of organic products.

Recently, more and more agricultural producers, representatives of agricultural management, education and science, international projects and programs have focused on organic farming and organic food. The gradual ecologization of the food products market, and the growing interest in the world in this type of product, makes it possible for Ukraine to become an active participant in the competition on it [1].

In accordance with the Law «On the Production and Circulation of Organic Agricultural Products and Raw Materials», the production of organic products (raw materials) is «the production activity of individuals or legal entities (including cultivation and processing), where such use excludes the use of chemical fertilizers, pesticides, genetically modified organisms (GMOs), preservatives, etc., and at all stages of production (cultivation, processing) the methods, principles and rules defined by this Law are used to obtain natural (ecologically pure) products, as well as the conservation and restoration of natural resources» [2]. Organic products are products obtained as a result of certified production in accordance with the requirements of the Law.

Separate requirements are set for the product disposal: the material used for packaging of the organic product should be made of natural raw material, which can be reused and which will not have a negative impact on the environment. Organic production has a number of economic, environmental and social benefits, and has a positive impact on public health.

The organic quality of the product is confirmed by a certificate issued by an accredited competent certification body. As information for the consumer, the packaging shall be labeled in accordance 
with the standards and information on the certification body. However, the vast majority of farms are certified by foreign certification companies in accordance with European «organic standards». There are 12 foreign and one Ukrainian certification authorities operating in Ukraine. Today the greatest demand for certification is observed in the following types of activities: crop production, animal husbandry, processing and sale of products; since 2009 Organic Standard Ltd. has started providing certification services for beekeeping, since 2010 - for fertilizers for organic agriculture.

The certification process consists of these stages, firstly, of the main one year control inspection, and secondly, of several additional inspections (announced and not announced) and, thirdly, of the process of evaluation, which results in receipt or refusal of the certificate [4]. That is, not the final product, but the entire process of production of organic products is certified. The certificate, which gives organic status, is a proof of compliance with the standards of organic production.

When introducing environmentally friendly production in agriculture, business entities are obliged to adhere to the principle of integral prevention of the formation of pollutants and sources of their occurrence.

The basis for the development of organic agriculture is its principles. Principle of care - organic agriculture aimed at maintaining and improving the health of soil, plants, animals, humans and the environment in general.

The principle of ecology - organic agriculture based on ecological functioning of natural systems and cycles and aims to support them. The principle of justice - organic farming is aimed to build trusting relationships and respect for the environment and living conditions.

The principle of care - organic agriculture is aimed at responsible attitude to the environment and its conservation for the present and future generations.

Principles of organic agriculture serve to encourage organic movement in all its diversity. They regulate development of IFOAM basics, programs and standards. Organic products are characterized by naturalness and safety of nutrition However, its cultivation has certain features, most of which today are negative for the country, prompting farmers to abandon growing it:

1. Ukraine lacks a sufficient number of registered certification centers that does not entitle producers to sell products as organic. Most of such products are equated at market prices to the usual.

2. Low number of qualified staff (agronomists, engineers, economists) specializing in the cultivation of organic products.

3. Unformed demand for organic products. More attention should be paid to the dissemination of information on organic production among the population.

4. Undeveloped organic products market. There are no officially registered wholesale and retail trade in organic products [5].

At the same time, the peculiarities of the production of organic produce also provide advantages for producers:

- food safety - the main factors for choosing organic products are food security (lack of chemical elements) and nutrition;

- environmental protection - the use of organic production, which is aimed at increasing soil fertility, reducing water pollution, improving animal health;

- taste qualities - due to the higher content of vitamins, a balanced amount of minerals, most organic products are better to taste;

- reduction of production costs - production costs on material resources are reduced in comparison with intensive technologies, due to the regularity of expenses for mineral fertilizers and plant protection products; 
- extraordinary profits - adjusted sales allow you to sell organic products at a price three times higher than the usual one;

- storage - organic products have a lower shelf life than usual [6].

Domestic producers through the irrational use of mineral and chemical agents in the production of agricultural products harm both land resources and people who consume manufactured products, the reason for this is the fact that agricultural producers neglect the damage to ecology, taking care only of their own benefit.

Agricultural production in Ukraine is in a state of ecological crisis. The reason for this is the intensification of land use combined with excessive cultivation of land.

In each country, the safe food market has its name according to the production technology. For example, in Germany, Switzerland, Italy and France, the products of non-refined products are designated as biological (BIO-products); in Sweden, Norway, Denmark and Spain - environmental (ECO-products); in Australia, England, the USA, Georgia and Russia - organic (ORGANIC products); in Canada - organic, biodynamic products; in Finland - natural, natural products, and in Estonia - as environmentally friendly [7].

In the EU, ecologically pure (organic) products are considered only that has been produced, processed and sold in accordance with the organic standards of Commission Regulation (EC) No. 889 / 2008 or the International Federation of Organic Agriculture (IFOAM) [8].

In Ukraine, the only legislative document regulating the rules and norms of production of environmentally friendly products are the Law of Ukraine «On organic production». According to it, organic products and raw materials should be produced in designated areas for organic farming. This category includes natural products and raw materials of plant and animal origin, forest, bee and fish products, which are grown, produced, processed, certified, labeled, stored and sold according to the rules of organic production. This product is intended for consumption in processed or unprocessed form, has biologically valuable qualities and healing properties [2].

Only in the EU, the number of «organic» farms has increased by more than 20 times over the past 15 years.

The main reasons for consumption of organic products are:

- environmental safety of food, high quality and freshness of products;

- higher taste properties of organic products;

- preservation of the natural environment in the process of production;

- absence of genetically modified organisms.

Nevertheless, despite the active development of organic products, the EU has limited opportunities in the development of this production. The main reasons for this are low quality soil characteristics and the widespread use of intensive technologies in agriculture. Taking into account this situation and tendencies of the development of the market situation of organic products of the European Union, Ukraine has the prospect of occupying its segment on it.

For Ukraine, a strategy for the introduction of environmentally friendly production is vital, which should identify ways to solve ecological and economic problems in a comprehensive way, and provide the prerequisites for creating an effective system for promoting the introduction of strategies and methods for such production by economic entities.

The financial crisis affecting Ukraine makes it possible to revisit the old benchmarks and to develop new directions of movement that lead to the search for new stable niches in the economy of the globalized world. The ever-growing interest in organic products in the world gives Ukraine the opportunity to be an active participant in the world market for organic products. 
Organic farming is developing at a very fast pace and today in 146 countries of the world statistics are being produced on organic food production. Among 100 countries - the largest producers of organic farming products, Ukraine ranks 16th, which is significant in terms of improving its competitive position in the global food market, as our country has outpaced a number of European countries at the pace of development of this segment [9].

According to Ukrainian experts, potential consumers of such in Ukraine, there are about $5 \%$ of the population of large cities willing to pay for it 30-50\% more than for usual products [4]. The maximum demand for organic produce is observed in the population aged 40-49 years (4.58 million people) and families with children under 7 years old ( 7.25 million people). This is explained, first of all, by the best financial situation of the first group of people and a responsible attitude to their health. Purchases of organic products are expected on the high quality and freshness of the products, the best taste properties of organic products, the lack of genetically modified organisms. In addition, the world is becoming more and more environmentally competent, people who seek to care for the environment and therefore choose organic products as such, the production of which causes no damage to the natural environment [11].

The development of the organic products market in Ukraine could be developed at a faster pace if it was not a deterrent factor like the relatively high cost of organic products and products. Prices for organic products are usually much higher than normal [12].

This price is due to the fact that the cost of organic products are delivery costs to the end user. Organic products have a limited shelf-life, requiring special processing and transportation. The high price is influenced by the unsaturation of the market by such products and long chain of customers. Also, the price is set for the cost of certification, inspection and premium for the higher risk of production.

At the present stage of economic development, information is important. The level of information directly affects the performance and relevance of the current needs of any sector of the economy. Along with the development of organic production, its information support is also being developed, which can significantly contribute to the development of the organic products market in Ukraine. Lack of information among consumers of organic products will hinder the active development of the organic market in Ukraine. The overwhelming majority of people do not understand the concept of «organic»; do not know how to distinguish an organic product from inorganic (marking); not aware of the benefits of organic matter or doubt about the availability of such; consider the concept of «organic» marketing process of producers, which simply stimulates more to pay - a crisis of confidence; are convinced that all «titles» (eco, organic, bio, etc.) can be purchased; do not understand "why pay more»; do not know where to buy organic products. Having decided to consume organic products, the consumer faces the problem of realizing his decision (small selection of organic substances in supermarkets, especially the products that are corrupted).

Analyzing the effectiveness of communication in European countries, almost all consumers have knowledge about organic products, and despite high prices, they are increasingly giving preference to such products. Large processing companies and retailers invest in promotion of organic products in order to improve their image and sales, and most countries have been conducting campaigns to raise awareness about organic matters.

For better consumer awareness of organic products and, accordingly, increasing demand for it, it is necessary to take into account the best practices of the leading EU countries, using advertisements that emphasize the benefits of organic products for human health, linking them with positive attributes such as «well-being», «life expectancy», «traditional cuisine», «folk culture».

Intensive marketing of organic products in Ukraine through the Internet has significant potential for the development of the internal market for organic products and can create, and further stimulate, consumer demand. This may contribute to a positive attitude of the public towards the organic 
sector in general and, in the majority, will stimulate consumption of organic products, the development of organic agricultural production.

Therefore, in our opinion, in order to protect consumers' rights, as well as eliminating marketing mixes between producers and consumers of organic products, it is expedient to create a website. Such site should contain information:

1. About all producers of organic products in Ukraine: their location, certification, assortment of products and their prices, terms of delivery and storage, according to which standards the products have passed the certification.

2. The definition of «organic products» and «organic production», an explanation of the benefits of organic production compared with traditional.

3. The place of sale and sale of organic products of each producer.

4. About the rules of product certification and its cost, possible consultation on certification issues for beginners.

5. About accredited certification bodies on the territory of Ukraine.

Information for growing, protecting and storing methods is important for some consumers. For starters and agrarians who have opted for organic production, information is needed that would reveal aspects of legislative support for the entire organic production process, from the stage of obtaining the status of organic producer and ending with the stage of selling certified organic products to the final consumer.

Summarizing the aforementioned generalization: the purpose of creating a website is systematization of Ukrainian «organic farms» for the development of the organic market in Ukraine, the formation of a wide range of quality food products and the introduction of a unified certification system.

The creation of the site poses the following tasks: creation of a network of manufacturers and formation of the internal market of organic products; assistance in the formation of the regulatory framework for the development of the organic products market; increase of public ecological consciousness; provision of information on the passage of the certification procedure; cooperation and exchange of experience with Ukrainian and foreign organizations; creation of a scientific and practical basis for the study, adaptation and implementation of world practice in Ukrainian farms; help producers to sell their products both on the domestic and on the external market; giving full and true information to the consumer about «organic farming» of Ukraine; protection of consumer rights; review of the range of products and orders online; creating a competitive environment and expanding access to organic products from different sectors of the population; the establishment of interaction between the organic producer and the consumer without intermediaries.

Creating and controlling the activities of such a site should take place at the state level. According to Art. 20 of the Law of Ukraine «On Organic Production» dated April 21, 2011 «Informational support for the production of organic products and raw materials is carried out by the central executive body on agrarian policy issues» [3]. This body is the Ministry of Agrarian Policy and Food of Ukraine.

In accordance with the Regulation on the Ministry of Agrarian Policy and Food of Ukraine, approved by the Decree of the President of Ukraine dated April 23, 2011, No. 500, the main tasks of the Ministry of Agrarian Policy of Ukraine are the formation and implementation of the implementation:

- state agricultural policy aimed at developing the agro-industrial complex and ensuring food security of the state;

- state policy in the fields of agriculture, livestock farming, horticulture, seedling, seedling, viticulture, food and processing industry, engineering and technical support of agro-industrial complex and agricultural machinery, agricultural advisory activity; 
- state policy on land relations, topographic and geodetic and cartographic activity, forestry and hunting economy, quality and safety of agricultural products, seeds and planting material, biological and genetic safety of agricultural plants and animals, soil fertility.

One of the tasks of creating a website is consumer protection. A large volume of products that is positioned by the manufacturer or seller as «ecological», «natural» or «biological» is not consistent environmental standards and does not have the appropriate quality certificates.

Manufacturers provide information about products that are not true, which is essentially a fraudulent buyer. The most common ways to deceive buyers are:

1. Unsolicited statements - the manufacturer spontaneously notes on packing that its product is «bio», «eco» or even «organic», at the same time not having any documents confirming these statements.

2. Concealment of harmful indicators - for example, occur the inscriptions «Without GMO» on the packaging of food products, but products marked with such a sign may contain potentially dangerous artificial food additives that may contribute to the formation of malignant tumors, but are allowed in Ukraine for use in the manufacture of food and drinks.

3. The use of obscure, confusing statements - described in general terms, not enough specific environmental assertions.

4. Labeling on the packaging of false information - some manufacturers try to emphasize highquality product specifications, applying certification of production management systems.

5. Environmental labeling in the theory of relativity - the product can be the most ecologically priority in its category, but still this choice is not in favor of health or the environment.

\section{Conclusions}

Recently, more and more agricultural producers, representatives of agricultural management, education and science, international projects and programs have focused on organic farming and organic food. The gradual ecologization of the food products market, and the growing interest in the world in this type of product, makes it possible for Ukraine to become an active participant in the competition on it.

For Ukraine, a strategy for the introduction of environmentally friendly production is vital, which should identify ways to solve ecological and economic problems in a comprehensive way, and provide the prerequisites for creating an effective system for promoting the introduction of strategies and methods for such production by economic entities.

The effective development of the organic market in Ukraine is hampered by lack of awareness and lack of consumer awareness of organic products and organic production.

In order to ensure consumers' awareness of organic products and create demand for it, it is advisable to use the best practices of the leading EU countries, an intensive advertising campaign through the media, the benefits of organic products for human health, linking them with positive attributes such as «well-being», «life expectancy», «traditional cuisine», «folk culture».

There is no single authorized body in Ukraine that monitors certified enterprises and an assortment of organic products at the national level. The level of information support for organic products market in Ukraine is unsatisfactory.

Therefore, in our opinion, in order to protect consumers' rights, as well as eliminating marketing discrepancies between producers and consumers of organic products, it is expedient to create a website. The purpose of the website is systematization of Ukrainian «organic farms» for the development of the organic market in Ukraine, the formation of a wide range of quality food products and the introduction of a unified certification system. One of the tasks of creating a 
website is consumer protection. The large volume of products that is positioned by the manufacturer or seller as «ecological», «natural» or «biological» does not meet environmental standards and does not have the appropriate quality certificates.

\section{References}

1. Shevchenko, O. (2012). Organic in Ukraine [Orhanik v Ukraini], Ekonomika APK, No. 11, s. 8 [in Ukrainian]

2. On the production and circulation of organic agricultural products and raw materials: Law of Ukraine, No. 425-VII, 03.09.2013. Date added: 05.04.2015 [Pro vyrobnytstvo ta obih orhanichnoi silskohospodarskoi produktsii ta syrovyny: Zakon Ukrainy, No. 425-VII, 03.09.2013, data onovlennia: 05.04.2015], available at: http://zakon3.rada.gov.ua/laws/show/ 425-18 [in Ukrainian]

3. Federation of Organic Movement of Ukraine, IFOAM [Federatsiia orhanichnoho rukhu Ukrayiny, IFOAM], available at: www.organic.com.ua [in Ukrainian]

4. Mosttenskaya, T. L. (2013). Prospects for the development of organic products of Ukraine [Perspektyvy rozvytku orhanichnykh produktiv Ukrainy], Ekonomika APK, No. 11, s. 1-14 [in Ukrainian]

5. The «Organic Era» Trade House [Torhovyi dim «Orhanik era»], available at: http://www.organicera.com.ua [in Ukrainian]

6. Zinchenko, S. (2013). Possibilities of organic [Vozmozhnosti organiki], Agro Perspektiva, No. 9 (116), s. 25 [in Russian]

7. Iliak, L. (2010). Ecologically pure production: foreign experience and Ukraine [Ekolohichno chyste vyrobnytstvo: zarubizhnyi dosvid ta Ukraina], Ekonomika APK, No. 3 (41), s. 14 [in Ukrainian]

8. Artysh, V. I. (2010). The development of world market of organic products [Rozvytok svitovoho rynku orhanichnoi produktsii], Ekonomika APK, No. 3, s. 113-116 [in Ukrainian]

9. Mylovanov, Y. V. (2013). The current state and ways of activating the organic movement in Ukraine [Potochnyi stan ta shliakhy aktyvizatsii orhanichnoho rukhu v Ukraini], Ekonomika APK, No. 5, s. 9-14 [in Ukrainian]

10. BIOLan Ukraine (2013), available at: http://www.biolan.org.ua/uk/news/?newsid=111 (Accessed 14 October 2013) [in Ukrainian]

11. Ratoshniuk, T. M. (2012). Economical mechanism of stimulation the production of environmentally friendly products [Ekonomichnyi mekhanizm stymuliuvannia vyrobnytstva ekolohichno chystykh produktiv], Ekonomika APK, No. 1 (25), s. 6 [in Ukrainian]

12. Ministry of agrarian politics and food of Ukraine [Ministerstvo ahrarnoi polityky ta prodovolstva Ukrainy], available at: http://minagro.gov.ua [in Ukrainian] 